\title{
THE SH2 DOMAIN-CONTAINING 5-PHOSPHATASE SHIP2 IS EXPRESSED IN THE GERMINAL LAYERS OF EMBRYO AND ADULT MOUSE BRAIN: INCREASED EXPRESSION IN N-CAM-DEFICIENT MICE
}

\author{
E. MURAILlE, ${ }^{a}$ D. DASSESSE, ${ }^{b}$ J. M. VANDERWINDEN, ${ }^{b}$ H. CREMER, ${ }^{c}$ B. ROGISTER, ${ }^{d}$ \\ C. ERNEUX ${ }^{\mathrm{a}}$ and S. N. SCHIFFMANN ${ }^{\mathrm{b} *}$ \\ ${ }^{a}$ Interdisciplinary Research Institute (IRIBHN), Université Libre de Bruxelles, Campus Erasme, Building C, \\ 808 Route de Lennik, 1070 Brussels, Belgium \\ ${ }^{b}$ Laboratory of Neurophysiology CP601, Université Libre de Bruxelles, Campus Erasme, Building C, 808 Route de Lennik, \\ 1070 Brussels, Belgium \\ ${ }^{c}$ Laboratoire de Génétique et Physiologie du Développement, IBDM, CNRS/INSERM/Université de la Méditerranée, \\ Campus de Luminy, 13288 Marseille cedex 9, France \\ ${ }^{\mathrm{d}}$ Center for Cellular and Molecular Neurobiology, University of Liege, Liege, Belgium
}

\begin{abstract}
The germinative ventricular zone of embryonic brain contains neural lineage progenitor cells that give rise to neurons, astrocytes and oligodendrocytes. The ability to generate neurons persists at adulthood in restricted brain areas. During development, many growth factors exert their effects by interacting with tyrosine kinase receptors and activate the phosphatidylinositol 3-kinase and the Ras/MAP kinase pathways. By its ability to modulate these pathways, the recently identified Src homology 2 domain-containing inositol polyphosphate 5-phosphatase 2, SHIP2, has the potential to regulate neuronal development. Using in situ hybridization technique with multiple synthetic oligonucleotides, we demonstrated that SHIP2 mRNA was highly expressed in the ventricular zone at early embryonic stages and subventricular zones at latter stages of brain and spinal cord and in the sympathetic chain. No significant expression was seen in differentiated fields. This restricted expression was maintained from embryonic day 11.5 to birth. In the periphery, large expression was detected in muscle and kidney and moderate expression in thyroid, pituitary gland, digestive system and bone. In the adult brain, SHIP2 was mainly restricted in structures containing neural stem cells such as the anterior subventricular zone, the rostral migratory stream and the olfactory tubercle. SHIP2 was also detected in the choroid plexuses and the granular layer of the cerebellum. The specificity of SHIP2 expression in neural stem cells was further demonstrated by (i) the dramatic increase in SHIP2 mRNA signal in neural cell adhesion molecule (N-CAM)-deficient mice, which present an accumulation of progenitor cells in the anterior subventricular zone and the rostral migratory stream, (ii) the abundant expression of $160-\mathrm{kDa}$ SHIP2 by western blotting in proliferating neurospheres in culture and its downregulation in non-proliferating differentiated neurospheres.

In conclusion, the close correlation between the pattern of SHIP2 expression in the brain and the proliferative and early differentiative events suggests that the phosphatase SHIP2 may have important roles in neural development. (C) 2001 IBRO. Published by Elsevier Science Ltd. All rights reserved.
\end{abstract}

Key words: phosphatidylinositol metabolism, brain development, ventricular zone, rostral migratory stream, N-CAM, neural stem cell.

*Corresponding author. Tel.: +32-2-5556407; fax: +32-2-5554121. E-mail address: sschiffm@ulb.ac.be (S. N. Schiffmann).

Abbreviations: bFGF, basic fibroblast growth factor; CCK, cholecystokinin; E, embryonic day; EDTA, ethylenediaminetetraacetate; EGF, epidermal growth factor; GFAP, glial fibrillary acidic protein; HB-GAM, heparin-binding growth-associated molecule or pleiotrophin; IGF-I, insulin-like growth factor-I; MAPK, mitogen-activated protein kinase; N-CAM, neural cell adhesion molecule; PBS, phosphate-buffered saline; PI 3-K, phosphatidylinositol 3-kinase; PTB, phosphotyrosine-binding domain; PtdIns $(3,4,5) \mathrm{P}_{3}$, phosphatidylinositol 3,4,5-trisphosphate; SH2, Src homology 2; Shc, Src homology 2 domaincontaining transforming protein 1; SHIP, Src homology 2 domain-containing inositol polyphosphate 5-phosphatase; SSC, saline sodium citrate; SVZ(a), subventricular zone (anterior); $\mathrm{VZ}$, ventricular zone.
During development, neurons, astrocytes and oligodendrocytes arise from specialized germinative zones that extend from periventricular regions of the telencephalon to the central canal of the spinal cord. These zones initially consist of a pseudostratified epithelium (ventricular zone, VZ) containing progenitor cells with a range of neural lineage potentials. This $\mathrm{VZ}$ gives rise to subventricular zones (SVZ) during later embryogenesis. Neurons and radial glia are generated within the early embryonic VZ (from embryonic day E10 to E15-16) whereas astrocytes and oligodendrocytes are generated from the SVZ during the late embryonic and postnatal periods (McKay, 1997). It is now well established that the capacity of these germinal layers to generate neurons persists postnatally and throughout life in adult animals in the anterior part of SVZ (SVZa) (Luskin, 1993; Doetsch and Alvarez-Buylla, 1996; Goldman et al., 
1997; Luskin, 1998; Garcia-Verdugo et al., 1998). In the adult, these neural stem cells migrate from the wall of lateral ventricles to the olfactory bulb following a defined pathway, the rostral migratory stream.

The stem cells within these germinal layers are subject of intense investigation. Elucidation of the environmental cues and intracellular cascades is of particular interest to understand how neurons are born, migrate and differentiate. Phosphoinositide turnover system acts as a signal transducing cascade in the CNS. The phosphatidylinositol 3-kinase (PI 3-K) pathway has been involved in many neuronal developmental events including migration and neuritogenesis (Ming et al., 1999), proliferation, survival, regulation of apoptosis (Shimoke et al., 1997; Klesse and Parada, 1998; Dolcet et al., 1999; Vaillant et al., 1999) and differentiation (Feldman et al., 1997). The pleiotropic effects of PI 3-K suggest that its activity must be highly regulated. Distinct forms of inositol and phosphatidylinositol 5-phosphatases selectively remove the phosphate from the 5-position of the inositol ring from both soluble and lipid substrates. These enzymes, that terminate the signal transduction processes initiated by PI 3$\mathrm{K}$, are essential for proper cell function (reviewed in Erneux et al., 1998; Majerus et al., 1999). The Src homology 2 (SH2) domain-containing inositol polyphosphate 5-phosphatase (SHIP) family is a recently described subset of type II 5-phosphatase. SHIPs are tyrosine-phosphorylated proteins with several interesting features: an amino-terminal SH2 domain, a central catalytic domain and, at the carboxyl tail, several NPxY motifs [able to interact with phosphotyrosine-binding domain (PTB)] and Src homology 3-interacting prolinerich motifs (Drayer et al., 1996; Pesesse et al., 1997; Erneux et al., 1998; Majerus et al., 1999; Rohrschneider et al., 2000). Because of their ability to interact with SH2/PTB-containing protein, such as Src homology 2 domain-containing transforming protein 1 (Shc) (Pradhan and Coggeshall, 1997), and to dephosphorylate phosphatidylinositol 3,4,5-trisphosphate $\left[\operatorname{Ptd} \operatorname{Ins}(3,4,5) \mathrm{P}_{3}\right]$ (Drayer et al., 1996; Pesesse et al., 1998), the SHIPs have the potential to regulate the Ras/MAP kinase pathway and many, if not all, PI 3K induced events.

SHIP1 is a $145-\mathrm{kDa}$ protein mainly expressed in hemopoietic cells (Liu et al., 1998) playing a negative regulatory role in hemopoiesis (Helgason et al., 1998) and immune response (Coggeshall, 1998; Hunter and Avalos, 1998) by modulating PtdIns(3,4,5) $\mathrm{P}_{3}$ levels (Scharenberg et al., 1998) and Ras/mitogen-activated protein kinase (MAPK) activity (Tridandapani et al., 1998). SHIP2 is a $160-\mathrm{kDa}$ protein sharing several properties with SHIP1 including catalytic activity (Scharenberg et al., 1998) and binding to Shc after cell stimulation (Habib et al., 1998; Muraille et al., 1999, 2000). In contrast to SHIP1, SHIP2 expression by western blotting was not confined to hemopoietic cells and was detected in muscular and nervous mouse tissues (Muraille et al., 1999). In addition, SHIP2 associates to Shc in growth factor and insulinstimulated human non-hemopoietic cell lines (Habib et al., 1998). Based on the detection of SHIP2 protein in murine brain and the potential regulatory role of SHIPs on cell division, we have explored the localization of
SHIP2 expression during mouse brain development in comparison to developing peripheral organs as well as in the adult brain using in situ hybridization technique with multiple synthetic 42-mer oligonucleotide probes and searched for the expression of SHIP2 protein in the neurosphere culture model.

\section{EXPERIMENTAL PROCEDURES}

\section{Animals}

Female BALB/c and C57BL/6 mice (6-10 weeks old) were purchased from IffaCredo (Bruxelles, Belgium) and maintained in our animal facility. Pregnancies were dated by inspecting females for the presence of a vaginal plug, the day of the plug being embryonic day zero (E0). Embryonic brains were examined at the following stages: E11.5, E16.5 and E18.5. Neural cell adhesion molecule (N-CAM)-deficient mice were generated on a C57BL/6 genetic background by Cremer et al. (1994). Note that all efforts were made to minimize both the suffering and the number of animals used. All experiments were conformed to European guidelines on the ethical use of animals.

\section{In situ hybridization}

Animals were killed by decapitation. Whole embryos and brains were quickly removed and frozen in 2-methylbutane cooled by dry ice. Fifteen micrometer-thick coronal sections were cut and thaw-mounted onto slides coated with poly-Llysine. Mounted tissue sections were stored at $-20^{\circ} \mathrm{C}$ until use. The hybridization technique was adapted from (Schiffmann et al., 1997). The sections were fixed in a buffered $4 \%$ formaldehyde solution freshly prepared from paraformaldehyde for 30 min and rinsed in phosphate-buffered saline (PBS) $0.1 \mathrm{M}$. All sections were dehydrated and dipped for $3 \mathrm{~min}$ in chloroform. After air drying, the sections were incubated overnight at $42^{\circ} \mathrm{C}$ with $0.35 \times 10^{6} \mathrm{cpm}$ per section of ${ }^{35} \mathrm{~S}$-labeled probes diluted in hybridization buffer, which consisted of $50 \%$ formamide, $4 \times$ saline sodium citrate (SSC: $0.15 \mathrm{M} \mathrm{NaCl}, 0.015 \mathrm{M}$ sodium citrate, $\mathrm{pH} 7.4), 1 \times$ Denhardt's solution $(0.02 \%$ each of polyvinylpyrolidone, bovine serum albumin, Ficoll), 1\% sarcosyl, $0.02 \mathrm{M}$ sodium phosphate at $\mathrm{pH} 7.4,10 \%$ dextran sulfate, yeast tRNA at $500 \mu \mathrm{g} / \mathrm{ml}$, salmon sperm DNA at $100 \mu \mathrm{g} / \mathrm{ml}$, and $60 \mathrm{mM}$ dithiothreitol. Compounds were provided by Sigma Chemicals (St. Louis, MO, USA). After hybridization, the sections were rinsed for $4 \times 15 \mathrm{~min}$ in $1 \times \mathrm{SSC}$ at $55^{\circ} \mathrm{C}$, dehydrated and covered with hyperfilm- $\beta$ max film (Amersham, Buckinghamshire, UK) for 2 weeks [cholecystokinin (CCK) and heparin-binding growth-associated molecule (HB-GAM) or pleiotrophin] or 5 weeks (SHIP2). After exposition, the corresponding slides were stained with hematoxylin before examination. The specificity of in situ hybridization histochemistry was assessed by the use of different antisense probes distributed throughout the cDNA sequence of SHIP2 and the comparison of SHIP2 distribution with the localization of different mRNAs using oligonucleotides probes, CCK (Schiffmann and Vanderhaegen, 1991) and pleiotrophin, HB-GAM (Vanderwinden et al., 1992), of the same size and similar guanosine-cytosine content. Corresponding sense SHIP2 probes, $10 \mu \mathrm{g} / \mathrm{ml}$ RNase (Sigma) pretreatment or incubation with labeled antisense probe in the presence of 100 -fold excess of unlabeled antisense probe were used as negative controls.

\section{Oligonucleotide probes}

Forty-two-mer oligonucleotide SHIP2 probes based on the sequence of mouse SHIP2 (accession number AF162781) were synthesized on an Applied Biosystems 381 DNA synthesizer with a GC to $\mathrm{AT}$ ratio between 45 and $65 \%$ : probe $\mathrm{P} 1$ (5'-CAGCTC CTGCTC TCCAGT CTGTGG TAAGCT CTGCTG CTGTAA-3', exon 7, base 1129-1170), probe P2 
A

(1)

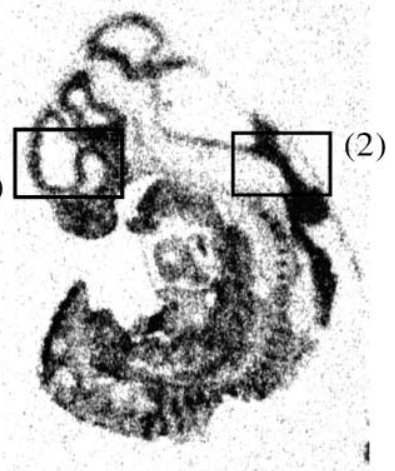

B

(1)

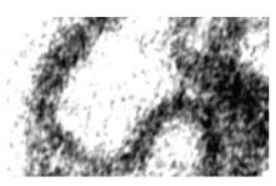

(2)

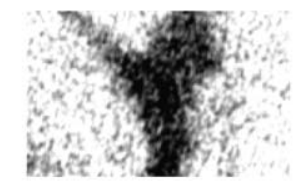

C

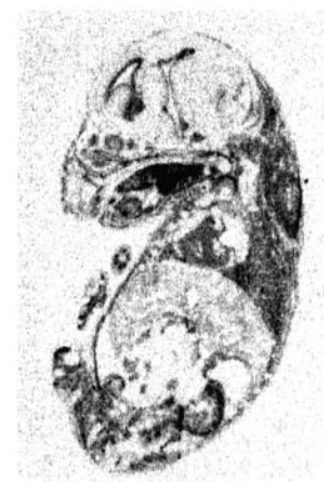

D

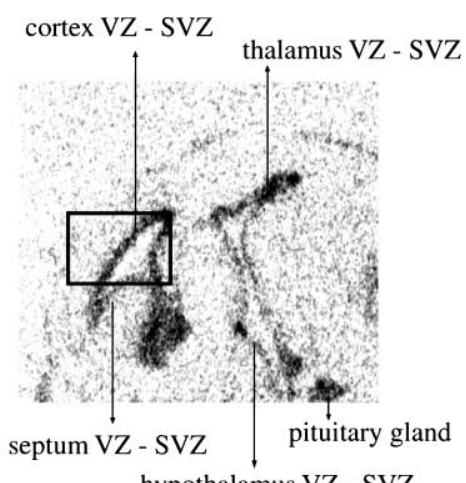

hypothalamus VZ - SVZ
$\mathrm{A}^{\prime}$

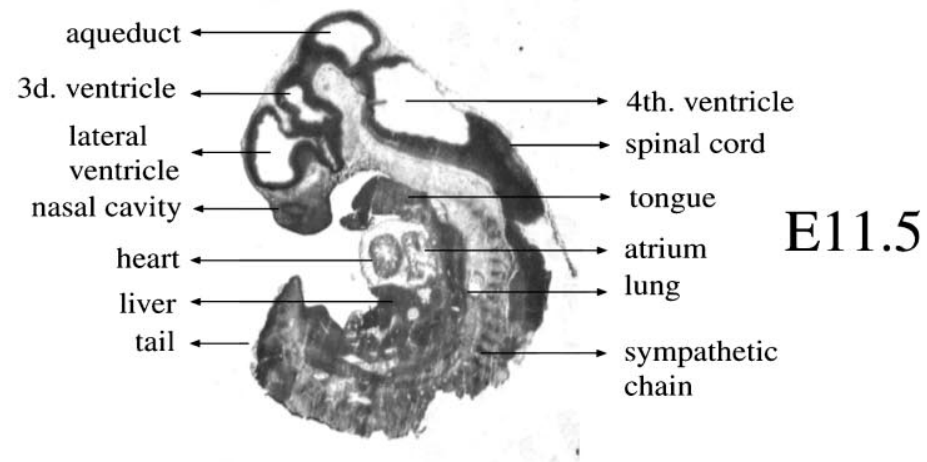

B'
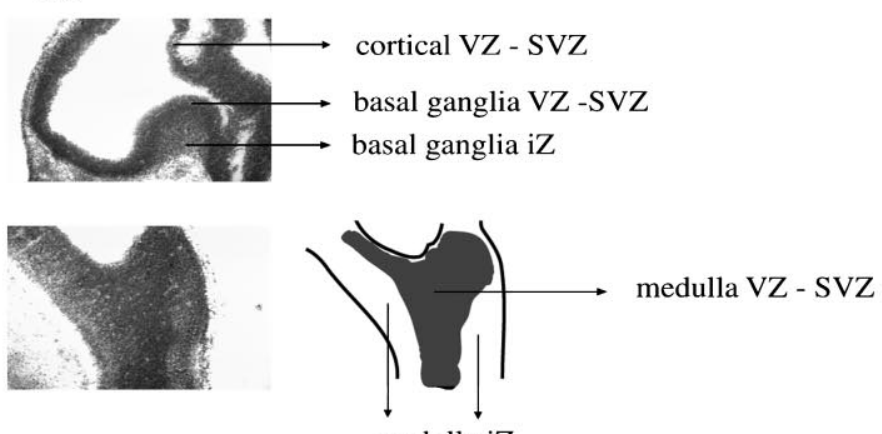

medulla iZ

$C^{\prime}$

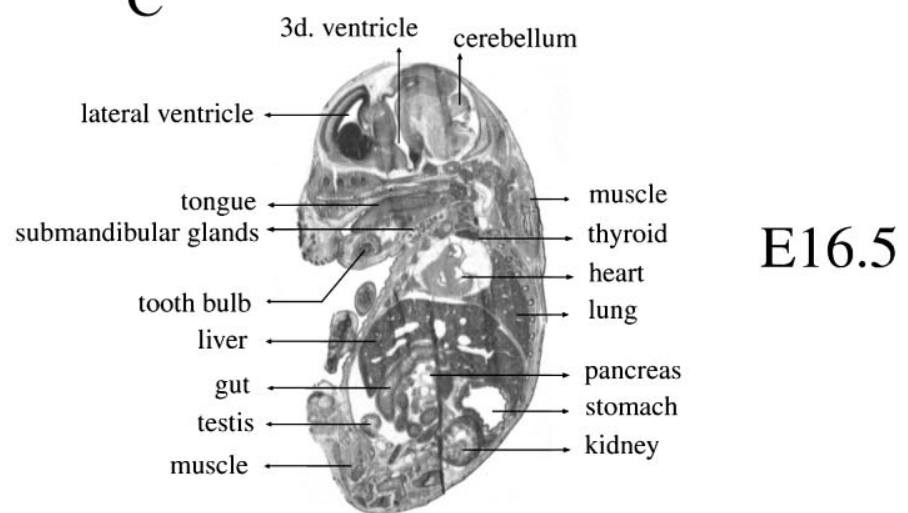

\section{D'}
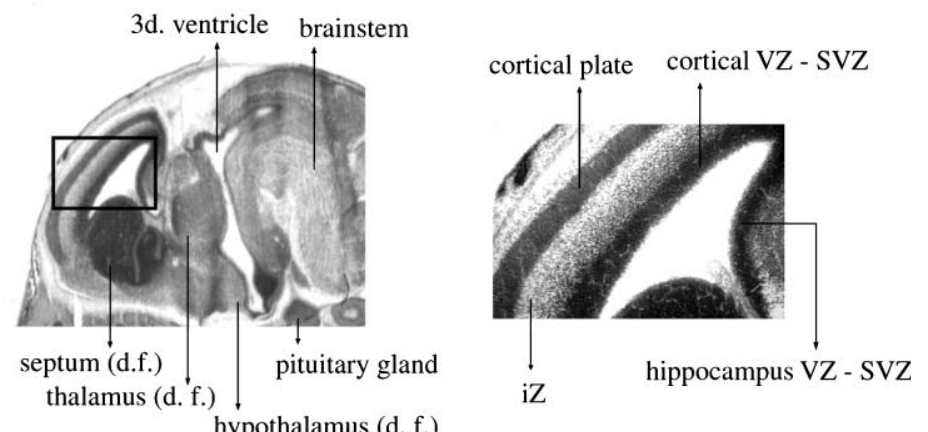

Fig. 1 (Caption overleaf). 
(5'-CATAGA TATCGT GGGGTA TAGTCA CTGTGA CCTCAT CCAGAG-3', exon 12, base 1751-1792), probe P3 (5'-CCTGAG CAGAGG CTCAAA CTCTCT CCTACT AATGTA GTTCAG-3', exon 16, base 2248-2289), probe P4 (5'-GGCTTC GATACT CTCAAA CTCAAT GTAGGC TTGATC TGAGGT-3', exon 20, base 2614-2655), probe P5 (5'-GGGCTG CTACTA CTTCCT GCTCAG ATGTCC CTTCTG ACTTCA-3', exon 26, base 3272-3313), probe P6 (5'-AGTGCT GAGCGT CCAGGC CCTGGA GCATAA TCTACC TCACTG-3', exon 26, base 3780-3821), probe P7 (5'-ACCCCA GCTTCC TCAAGG TCTTCC TCAGTG ATGTCA CTGAGA-3', exon 28, base 4065-4106). Probes were labeled with $\left[\alpha-{ }^{35}\right.$ S $]$ dATP (DuPont-NEN, Boston, MA, USA) at their $3^{\prime}$ end by terminal DNA deoxynucleotidylexotransferase (Gibco-Beth. Res Labs., Gaithersburg, MD, USA) and purified with a nucleic acid purification cartridge (Nensorb/ DuPont-NEN).

\section{Image analysis}

Developmental stages of mouse embryo were assessed according to the atlas of mouse development of Theiler (1989). Embryonic brain structures were identified according to the atlas of embryonic rat brain of Altman and Bayer (1995) and Schamra et al. (1992). Following the convention of the atlas, structures that could not be identified due to their lack of differentiation were referred to as differentiating fields. Two hundred sixty-six gray level images from hybridization film and corresponding images from the same hematoxylin-stained section were generated with the public domain NIH image 1.61 program (National Institute of Health, USA) using a Power Macintosh G3 and a CCD video camera (Dage-MTI, Indiana, USA) with fixed gain and black level.

\section{Preparations of neurosphere cultures}

The striata were removed from E16 NMRI mice (Iffacredo, Brussels, Belgium) and mechanically dissociated before cell plating as previously described (Reynolds et al., 1992; Ben-Hur et al., 1998). In. brief, viable cells were seeded at $2 \times 10^{5}$ cells $/ \mathrm{ml}$ in uncoated T25 tissue culture flasks (Sarstedt, Hoogstraten, Belgium). Culture medium consisted of $5 \mathrm{ml}$ of Dulbecco's modified Eagle's medium (DMEM)/F12 (1:1, v/v) complemented by B27 and N2 supplement (both from Life Technology, Gent, Belgium) in the presence of $20 \mathrm{ng} / \mathrm{ml}$ of epidermal growth factor (EGF; PeproTech, Immunosource, Zoersel-Halle, Belgium). The serum-free medium was renewed (1/2) after 2 days. Every other day, $20 \mathrm{ng} / \mathrm{ml}$ of EGF were added to the medium. Cells proliferated and formed spheres in suspension. Proliferating neurospheres are collected after 7 days in culture for the purpose of protein extraction or processed for differentiation. For this latter purpose, neurospheres with the same size were plated on poly-D-lysine/fibronectin-coated T25 tissue culture flasks. After $3 \mathrm{~h}$, spheres have adhered and medium is renewed with $5 \mathrm{ml}$ of DMEM/F12 (1:1, v/v) complemented by B27 and N2 supplement but without EGF. After 5 days, cells are collected for protein extraction. In those conditions, after triple immunolabeling of the differentiated cells, one can observe neurons, astrocytes and oligodendrocytes but no more nestin-positive (Ben-Hur et al., 1998.

\section{Western blot analysis}

Immunoblot analysis of SHIP2, EGF receptor and glial fibrillary acidic protein (GFAP) have been performed as reported previously (Muraille et al., 1999). In brief, cells were washed in cold PBS and lysed in $10 \mathrm{mM}$ Tris- $\mathrm{HCl}$ cold buffer, $\mathrm{pH}$ 7.5 , supplemented with $150 \mathrm{mM} \mathrm{KCl}, 0.5 \% \mathrm{NP}-40,100 \mathrm{mM}$ $\mathrm{NaF}, 2 \mathrm{mM}$ mercaptoethanol, $1 \mathrm{mM} \mathrm{Na} \mathrm{VO}_{4}$, protease and phosphatase inhibitors $(1 \mathrm{nM}$ okadaic acid, $5 \mu \mathrm{M}$ leupeptin, $0.1 \mathrm{mM}$ pefabloc, $1 \mathrm{mM}$ EDTA, $20 \mu \mathrm{g} / \mathrm{ml}$ calpain inhibitors I and II), for $30 \mathrm{~min}$ at $4^{\circ} \mathrm{C}$ under agitation. This was followed by centrifugation at $13000 \mathrm{rpm} / \mathrm{min}$ for $10 \mathrm{~min}$. The soluble fractions were boiled in Laemmli sample buffer and electrophoresed as previously described (Muraille et al., 1999). The blots were blocked with $1 \%$ milk powder and $1 \%$ bovine serum albumin in a buffer containing $10 \mathrm{mM}$ Tris- $\mathrm{HCl}, \mathrm{pH} 8,150 \mathrm{mM} \mathrm{NaCl}$ and $0.05 \%$ NP-40. Western blots were incubated with the relevant antisera diluted $1 / 250$ for anti-SHIP2, $1 / 500$ for anti-EGF receptor and 1/1000 for anti-GFAP. Anti-SHIP2 antibodies were generated in rabbits as described previously (Muraille et al., 1999). Goat polyclonal antibodies specific to EGF receptor were obtained from Santa Cruz (CA, USA). Rabbit polyclonal antibodies to GFAP were obtained from Sigma. Immunodetection was visualized using peroxidase-conjugated secondary antibody, obtained from Amersham Life Science (Roosendael, The Netherlands) and the enhanced chemoluminescence system (NEN Science Product, Boston, MA, USA). Protein concentration was estimated as previously described (Muraille et al., 1999).

\section{RESULTS}

\section{SHIP2 probe characterization and signal specificity}

Alternative spliced forms have been described for SHIP1 (Kavanaugh et al., 1996; Rohrschneider et al., 2000; Wolf et al., 2000) and rat SHIP2 (Ishihara et al., 1999). To test the possibility that the exonic localization of probes may affect the apparent SHIP2 distribution, seven antisense probes widespreadly distributed in the mouse SHIP2 sequence (Schurmans et al., 1999) were prepared (see Experimental procedures). Hybridization with these SHIP2 probes on embryos at E16.5 (data not shown) and adult brain (data not shown) yielded similar results. In order to increase the signal intensity, we used a 1/1 mixture of antisense probes P2 and P4 for all subsequent SHIP2 hybridizations. RNase pretreatment (data not shown) as well as competition with a 100-fold excess of the same unlabeled SHIP2 probes (data not shown) abolished the labeling. Hybridization with sense SHIP2 probes yielded no labeling (data not shown). Hybridization with the labeled pleiotrophin (HB-GAM) (data not shown) and CCK (data not shown) antisense probes yielded patterns of expres-

Fig. 1. SHIP2 expression in a parasaggital section of E11.5 (A, B) and E16.5 (C, D) mouse embryo. At E11.5 (A, B), the SHIP2 mRNA expression pattern demonstrates a high expression of SHIP2 in the VZ and SVZ from the telencephalon to the spinal cord (A). No expression was detected in intermediate zones (iZ) of the ganglionic eminence or the medulla (B1 and B2). SHIP2 expression was also detected in the sympathetic chain, muscles such as in the tongue and heart. At E16.5 (C, D), in the CNS, SHIP2 expression is restricted to the VZ and SVZ bordering the lateral, third (3rd) and fourth (4th) ventricles. No signal was detected in differentiating cerebral fields (C, D). See for instance the cortical plate and intermediate zones of the differentiating cerebral cortex and the differentiating striatum (D). SHIP2 is highly expressed in all muscular tissues (C). A moderate signal is observed in lung (C). We detected a strong signal in the cortex area of the kidney (C). Very low expression is detected in liver $(C)$. $\left(\mathrm{A}^{\prime}\right),\left(\mathrm{B}^{\prime}\right),\left(\mathrm{C}^{\prime}\right)$ and $\left(\mathrm{D}^{\prime}\right)$ Light micrographs of hematoxylin-stained sections. d.f., differentiated field. 
A

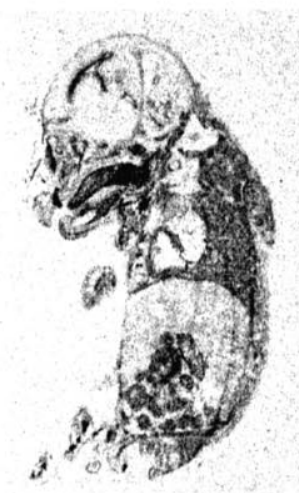

B

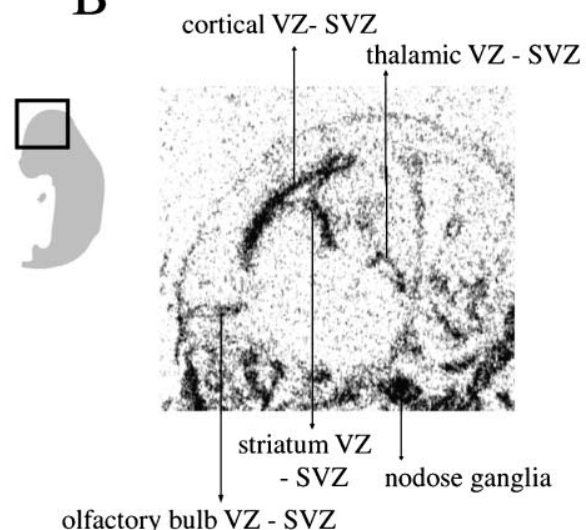

$\mathrm{C}$
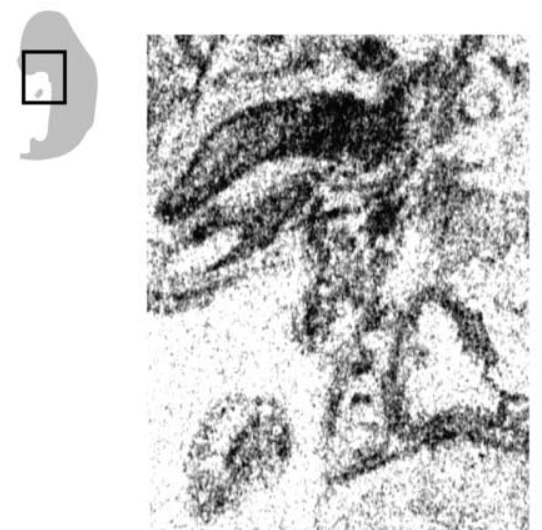

$\mathrm{A}^{\prime}$

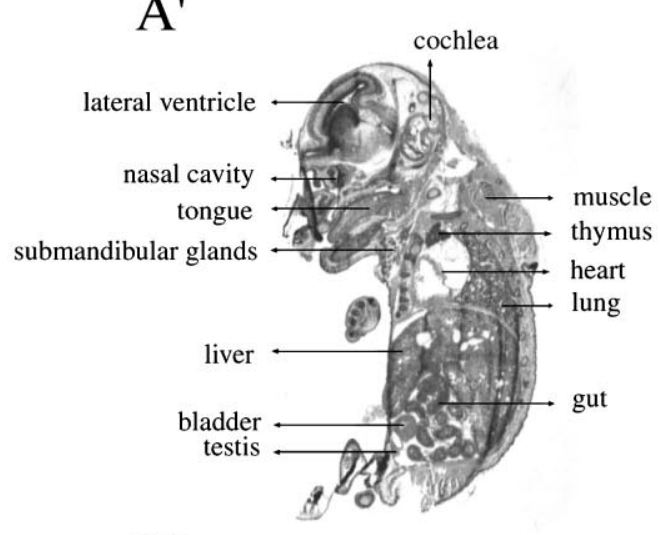

B' $^{\prime}$

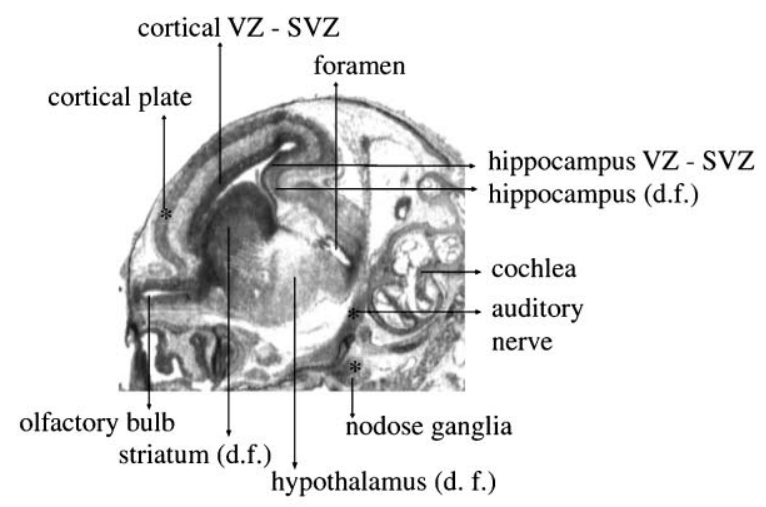

$\mathrm{C}^{\prime}$

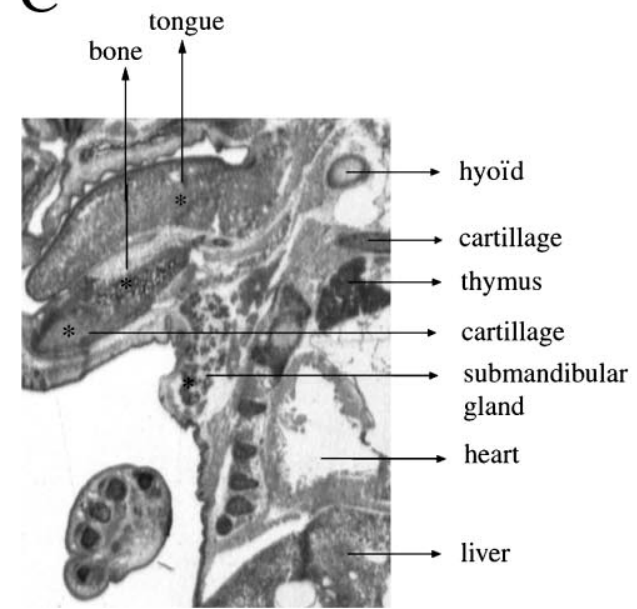

Fig. 2. SHIP2 expression in parasaggital sections of E18.5 mouse embryo. In the CNS, SHIP2 expression is restricted to the VZ and SVZ bordering the lateral, third (3rd) and fourth (4th) ventricles. No signal was detected in differentiating cerebral fields (A, B). SHIP2 is highly expressed in all muscular tissues (particularly in tongue) (A, C). A moderate signal is observed in lung (A). SHIP2 signal is present in bone tissues but not in cartillage (A, C). Moderate expression of SHIP2 is observed in the gut, the testis and the bladder (A). Very low expression is detected in liver (A). ( $\left.\mathrm{A}^{\prime}\right),\left(\mathrm{B}^{\prime}\right)$ and $\left(\mathrm{C}^{\prime}\right)$ Light micrographs of hematoxylin-stained sections. d.f., differentiated field.

sion in agreement with previously obtained results (Schiffmann and Vanderhaegen, 1991; Vanderwinden et al., 1992) and totally different to SHIP2 distribution. Taken together, these data demonstrate the specificity to our SHIP2 probes and suggest the absence of significant spliced forms of SHIP2 results, in line with Wolf et al. (2000).

\section{SHIP2 mRNA expression during development}

Table 1 summarizes the embryological expression of SHIP2 mRNA. Although SHIP2 mRNA was expressed in many systems at various levels, its expression was prominent in the nervous system and the muscular system. 
A

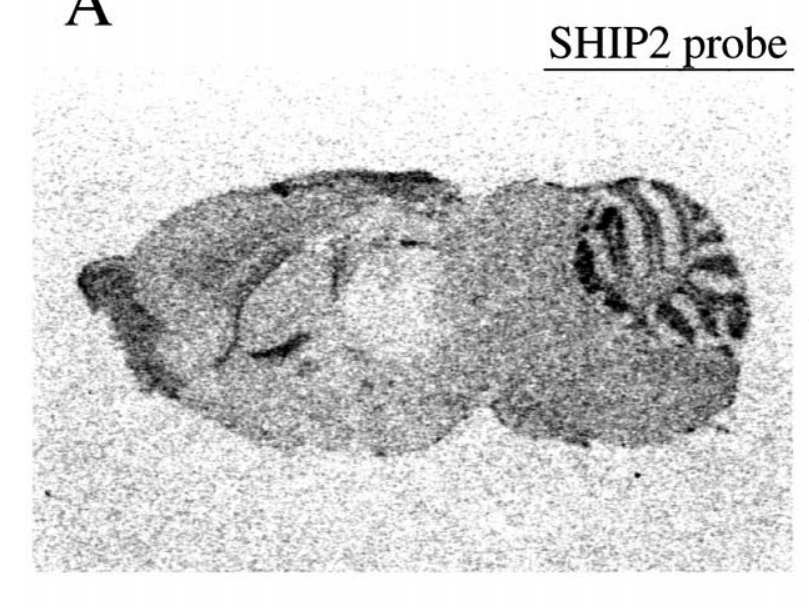

B

\section{wild type}

(1)
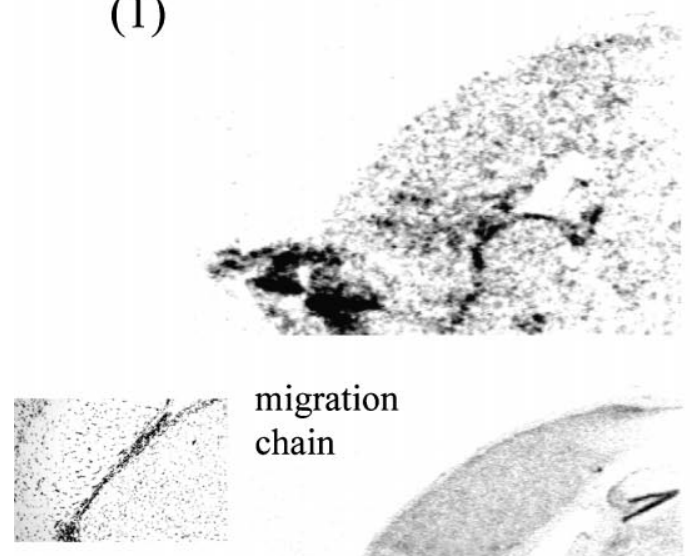

(1')

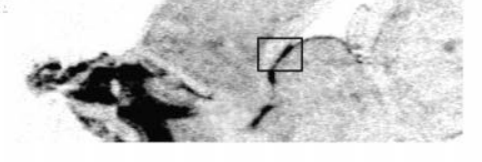

(2)

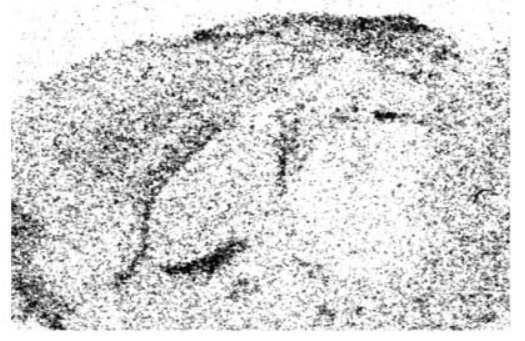

(2')

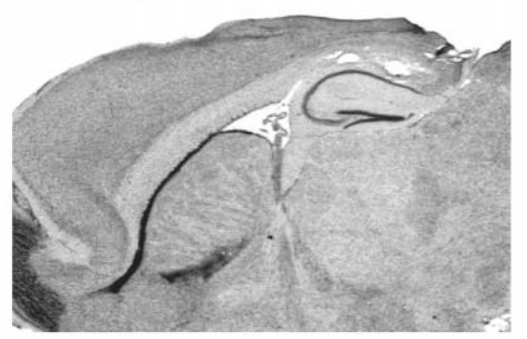

$A^{\prime}$

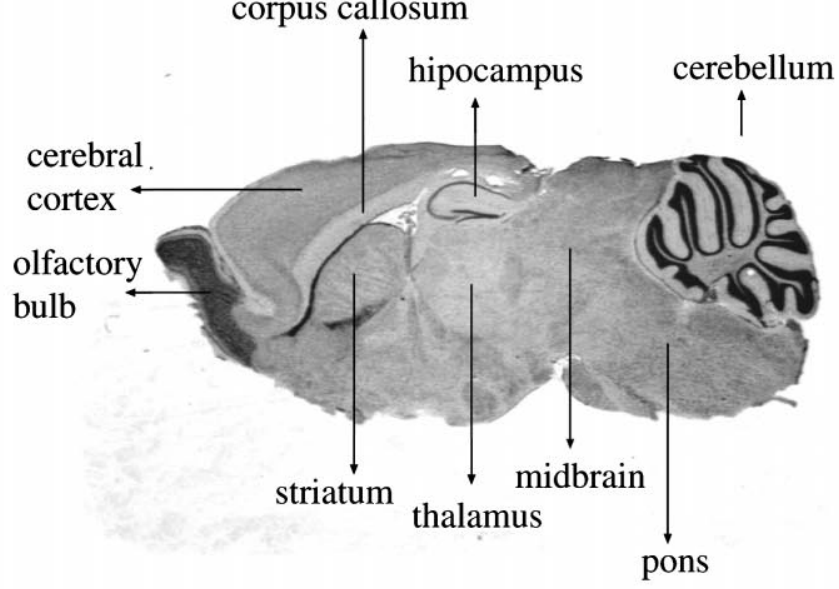

N-CAM -/-

(3)

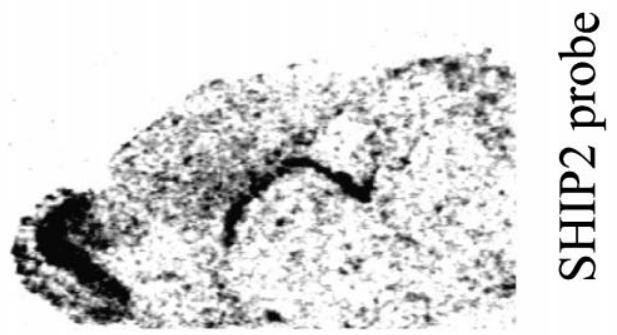

migration

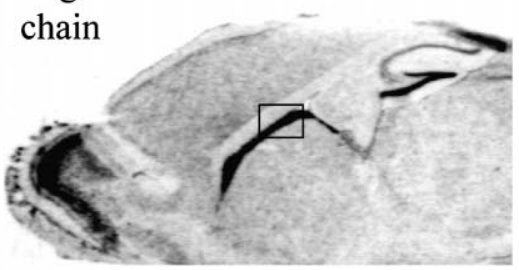

(4)

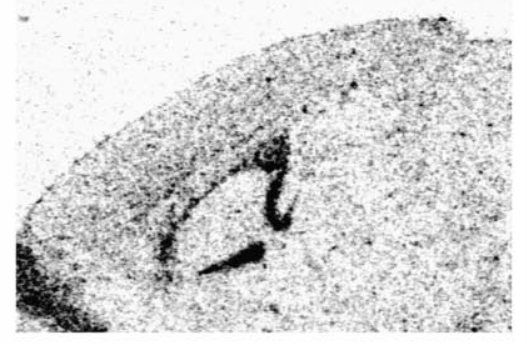

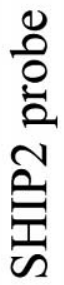

(4')

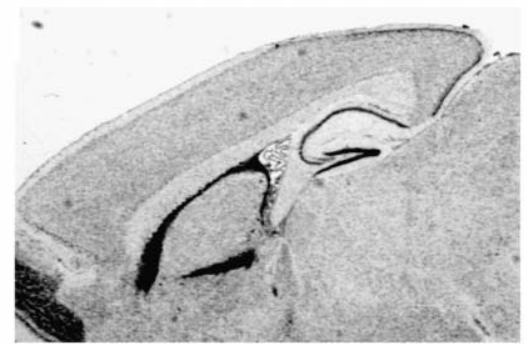

Fig. 3. 
Table 1. SHIP2 mRNA expression

\begin{tabular}{|c|c|c|c|}
\hline & E11.5 & E16.5 & E18.5 \\
\hline \multicolumn{4}{|l|}{ Nervous system: } \\
\hline Cortex $\mathrm{GL}^{\mathrm{a}}$ & +++ & +++ & +++ \\
\hline Cortex (d.f. $)^{b}$ & l & - & - \\
\hline Striatum GL & +++ & +++ & +++ \\
\hline Striatum (d.f.) & I & - & - \\
\hline Thalamus GL & +++ & +++ & +++ \\
\hline Thalamus (d.f.) & l & - & - \\
\hline Hypothalamus GL & +++ & +++ & +++ \\
\hline Hypothalamus (d.f.) & l & - & - \\
\hline Pons GL & +++ & +++ & +++ \\
\hline Pons (d.f.) & I & - & - \\
\hline Choroid plexus & & +++ & +++ \\
\hline \multicolumn{4}{|l|}{ Endocrine organs: } \\
\hline Thyroid & & ++ & \\
\hline Pituitary gland & & ++ & \\
\hline \multicolumn{4}{|l|}{ Digestive system: } \\
\hline Stomach & & ++ & \\
\hline Liver & $-/+$ & $-1+$ & $-1+$ \\
\hline Pancreas & & - & \\
\hline Gut & & + & ++ \\
\hline \multicolumn{4}{|l|}{ Respiratory system: } \\
\hline Nasal epithelium & & ++ & ++ \\
\hline Lung & ++ & ++ & ++ \\
\hline \multicolumn{4}{|l|}{ Excretory system: } \\
\hline Kidney (cortex) & & +++ & \\
\hline Bladder & & & ++ \\
\hline \multicolumn{4}{|l|}{ Muscular system: } \\
\hline Heart & ++ & +++ & +++ \\
\hline Striated muscles & +++ & +++ & +++ \\
\hline Smooth muscles & & +++ & +++ \\
\hline \multicolumn{4}{|l|}{ Skeleton: } \\
\hline Bone & & ++ & ++ \\
\hline Cartilage & & - & - \\
\hline \multicolumn{4}{|l|}{ Other organs: } \\
\hline Testis & & ++ & ++ \\
\hline Thymus & & + & + \\
\hline Lung & & ++ & ++ \\
\hline Submandibular glands & & ++ & ++ \\
\hline Tooth bud & & ++ & \\
\hline
\end{tabular}

+++ , high; ++ , moderate; + , low; - , undetectable; /, structure not present at this stage.

${ }^{a}$ GL, germinal layer (ventricular or subventricular zone depending on the stage of development).

${ }^{b}$ d.f., differentiated field.

Nervous system. A high expression of SHIP2 mRNA was already detected in E11.5 embryo. At this stage, the labeling was restricted to the VZ and SVZ of all examined areas from the telencephalon to the spinal cord (Fig. 1A). An intense labeling was also observed in the neuroepithelium bordering the otic vesicle (data not shown) and in the developing sympathetic chain (Fig. 1A). Noteworthy, no expression was detected in intermediate zones in brain areas where these layers have started their formation such as in the ganglionic eminence (Fig. 1B1) or the medulla (Fig. 1B2).

At E16.5, the SHIP2 mRNA expression remained restricted to the VZ and SVZ. This was prominent in the telencephalic and diencephalic VZ and SVZ bordering the lateral ventricle and the third ventricle, respectively (Fig. 1C). At this stage, no signal was detected in differentiating cerebral fields such as cortex, striatum, thalamus, hypothalamus, brainstem and cerebellum. This is exemplified by the absence of labeling in the cortical plate and intermediate zone of the developing cerebral cortex (Fig. 1D) and in the septal differentiating field. A faint labeling could be detected in the choroid plexus in the fourth ventricle (Fig. 1C).

At E18.5, the brain expression of SHIP2 mRNA was still restricted to the proliferative $\mathrm{VZ}$ and SVZ (see the cortical, olfactory bulb, striatal and hippocampal neuroepithelia in Fig. 2A and B). Such as in earlier stages, no labeling could be detected in more differentiated zones of the cerebral structures (see the cortical plate and the striatal differentiating field in Fig. 2B). At this stage, high expression was also detected in extracranial nervous ganglia, probably nodose ganglia (Fig. 2B).

Note that at all examined stages, no in situ hybridization signal could be detected in the cerebellar external generative layer (see Fig. 1C).

Muscular system. SHIP2 mRNA was highly expressed in muscular tissue throughout the development. SHIP2 was observed in heart from E11.5 to E18.5 and in all striated (specially the tongue) and smooth muscles at E16.5 (Fig. 1C) and E18.5 (Fig. 2C).

Squeleton. SHIP2 mRNA was expressed in bone tissues at E16.5 (Fig. 1C) and E18.5 (Fig. 2A and C). In contrast, no labeling was seen in cartilage at any studied.

Respiratory system. Moderate level of SHIP2 mRNA was observed in the epithelium of the nasal cavity and in the lung at E16.5 (Fig. 1C) and E18.5 (Fig. 2A).

Digestive system. Moderate expression of SHIP2 mRNA was detected in the gut at E16.5 (Fig. 1C) and E18.5 (Fig. 2A). Very low expression was detected in liver at E16.5 and E18.5. No expression was observed in the pancreas.

Urogenital and excretory system. At E16.5 (Fig. 1C) and E18.5 (Fig. 2A), the testis and the bladder were

Fig. 3. (A) In situ hybridization analysis of SHIP2 expression in a parasaggital section of adult mouse brain. SHIP2 mRNA expression was detected in restricted areas of adult brain. SHIP2 signal is observed in the SVZa, in all parts of the rostral migratory stream and in the olfactory bulb. A moderate expression was also detected in the granular layer of cerebellum. Note that SHIP2 signal was not detected in certain high cellular density areas, such as pyramidal layer of the adult hippocampus. A high level of expression was observed in all choroid plexuses. (B) In situ hybridization analysis of SHIP2 expression in brain parasaggital sections of wild-type (B1, B2) and N-CAM-deficient mice (B3, B4). Accumulation of migratory precursors in the rostral migratory stream of N-CAM-deficient mouse was correlated to an increase in the SHIP2 labeling. This could be seen in the anterior subventricular zone and at all levels of the rostral migratory stream. Note the dramatic enlargement of the rostral migratory stream beneath the corpus callosum revealed in hematoxylin-stained sections (insets in $\left.\mathrm{B} 1^{\prime}, \mathrm{B} 3^{\prime}\right) . \mathrm{A}^{\prime},\left(\mathrm{B} 1^{\prime}\right),\left(\mathrm{B} 2^{\prime}\right),\left(\mathrm{B} 3^{\prime}\right)$ and $\left(\mathrm{B} 4^{\prime}\right)$ Light micrographs of hematoxylin-stained sections. 


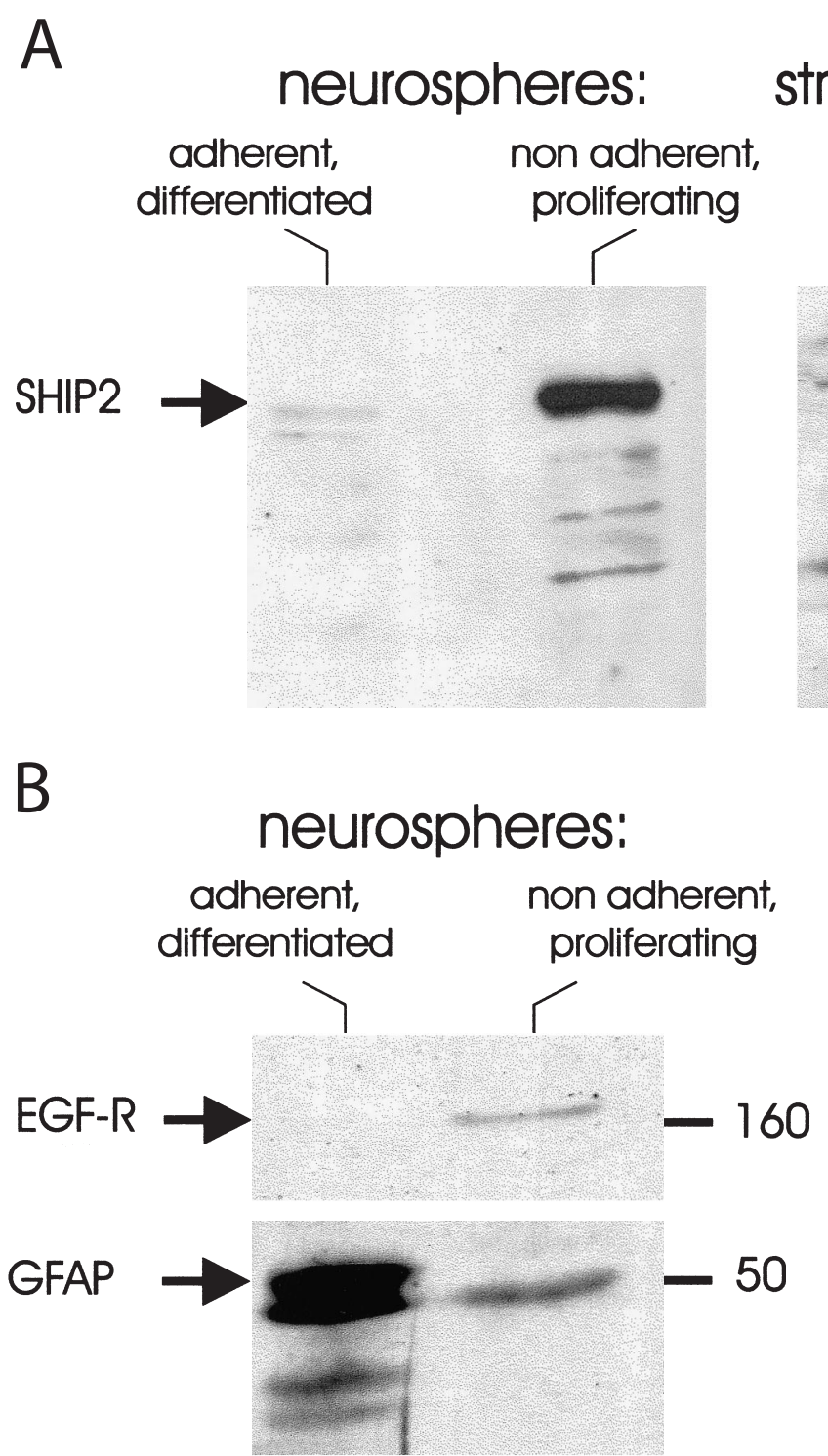

Fig. 4. Comparison of the expression levels of SHIP2 protein in proliferating and differentiated neurospheres. The expression levels of SHIP2 (A) EGF receptor and GFAP (B) were compared by immunoblot analysis of $107 \mu \mathrm{g}$ of protein from whole cell lysates of proliferating neurospheres, $133 \mu \mathrm{g}$ of differentiated neurospheres and $107 \mu \mathrm{g}$ of striatum, as indicated. Samples were resolved on sodium dodecyl sulfate-polyacrylamide gel electrophoresis (SDS-PAGE) gels and probed with antiSHIP2, anti-EGF receptor and anti-GFAP, as indicated. The data are representatives of two separate experiments. The positions of molecular mass markers are indicated (in $\mathrm{kDa}$ ) at the right. SHIP2, EGF receptor and GFAP molecular masses $(150-160 \mathrm{kDa}, 160 \mathrm{kDa}$ and $50 \mathrm{kDa}$, respectively) are indicated by arrows.

positive for SHIP2 mRNA expression. A strong signal was also detected in the cortex area of the kidney.

\section{SHIP2 $\mathrm{mRNA}$ expression in adult brain}

In the adult brain, SHIP2 mRNA expression was detected only in restricted areas (Fig. 3A). The most conspicuous labeling was found in the migration pathway of olfactory bulb progenitor cells. SHIP2 mRNA expression was observed in the SVZa, in all parts of the migration chain constituting the rostral migratory stream and finally in the olfactory bulb itself (Fig. 3A, B). In this latter structure, SHIP2 mRNA expression was observed in the granular and glomerular layers (Fig. 3A).
A high SHIP2 mRNA expression was also observed in a small area ventral to the striatum that contains cells morphologically identical to cells constituting the rostral migratory chain (see Fig. 3B). A high level of expression was also observed in choroid plexuses (see Fig. 3B4).

No significant expression was detected elsewhere in the brain, except in the cerebellum. In this structure, a moderate SHIP2 expression was observed in the granular layer (Fig. 3A). We are aware that structures containing high cellular density could be subject to technical artefacts. However, all controls (different antisense probes giving similar results, absence of signal with sense probes, following RNase pretreatment or in condition of competition, see Fig. 1) converge to exclude such 
hypothesis. Moreover, no labeling was observed in several other areas containing high cellular density such as the pyramidal layer of the adult hippocampus or the cortical plate and striatal differentiating field in embryos (see Figs. 1 and 2).

Mice deficient for all splice variants (Cremer et al., 1994; Chazal et al., 2000) or only the 180-kDa isoform (Tomasiewicz et al., 1993) of N-CAM show an accumulation of migrating precursors from SVZ along the rostral migratory stream leading to a reduction in olfactory bulb size and granule cell density. In order to confirm the specificity of the SHIP2 expression observed in cells in the SVZa and in the rostral migratory stream and to address the putative effect of N-CAM deficiency on SHIP2 level of expression, we examined the expression of SHIP2 mRNA in the adult brain of N-CAM knockout mice. The accumulation of migrating precursors correlated with an increase in SHIP2 signal (Fig. 3B3, B4). The enlargement of the rostral migratory stream beneath the corpus callosum (Fig. 3B3, B4) revealed by the hematoxylin stain on parasaggital sections was associated with a dramatic increase in the size of the SHIP2 mRNA labeled region. This could be similarly observed at the level of the SVZa where an increase in SHIP2 mRNA labeling was associated with an increase in the cellular content (Fig. 3B).

\section{SHIP2 protein expression in neurosphere cultures}

All results described up to this point concern the localization of the mRNA encoding SHIP2. It would be highly relevant to address the distribution of the SHIP2 protein to validate and reinforce the functional significance of its selective expression in germinal layers. We have previously developed a specific anti-SHIP2 polyclonal antibody useful in the detection of this protein by western blotting in several cell lines or tissue extracts (Muraille et al., 1999, 2000). We have now tested this antiserum on embryo or adult tissues including the brain using various protocols of immunohistochemistry but were unfortunately unable to detect any specific SHIP2 immunoreactivity (data not shown). To our knowledge, commercial antibody specific to SHIP2 is not yet available and this therefore precludes the possibility to detect the SHIP2 protein in situ. Nevertheless, to tentatively address the localization of the SHIP2 protein, we have used the model of neurosphere cultures. These cultures obtained from dissociated E16 mouse striatal primordia have been previously characterized and depending on the culture conditions, formed clusters of proliferating undifferentiated cells expressing nestin and EGF receptor or clusters of differentiated neuronal and glial cells expressing specific proteins like GFAP or microtubule-associated protein-2 (MAP-2) (Reynolds et al., 1992; Ben-Hur et al., 1998; Tropepe et al., 1998). Protein extracts from proliferating or differentiated neurospheres were subject to western blot analysis using the SHIP2 antibodies. As shown in Fig. 4, an intense protein band at the expected size of about $160 \mathrm{kDa}$ is detected in extracts of proliferating neurospheres and of E16 striatal tissue used as a control whereas only a very faint signal was detected for differentiated neurospheres. SHIP2 runs on sodium dodecyl sulfate (SDS) gels as a $160-\mathrm{kDa}$ protein (Muraille et al., 1999). This could also be shown in transfected COS-7 or CHO cells (data not shown). The lower molecular weight bands are artifactual due to the use of a crude serum for SHIP2 immunodetection as shown before in a series of mouse tissues (Muraille et al., 1999). We have also tested the validity of our preparations using antisera against specific markers of either proliferating or differentiated neurospheres. As expected, GFAP were detected exclusively in differentiated preparations whereas EGF receptor was detected in proliferating neurospheres (Fig. 4).

\section{DISCUSSION}

We have shown that during mouse embryonic development, SHIP2 5-phosphatase was highly expressed in the germinal layer or neuroepithelium of brain and spinal cord throughout the embryonic development, whereas no significant expression was detected in regions containing migrating or more differentiated cells. In the periphery, SHIP2 mRNA expression was intense in the developing muscular tissues and moderate in several other organs. In the adult brain, SHIP2 expression was mainly detected in structures containing neural stem cells such as the SVZa, the rostral migratory stream and the olfactory tubercle. The SHIP2 expression was dramatically increased in N-CAM-deficient mice which present an accumulation of these progenitor cells in the SVZa and the rostral migratory stream (Tomasiewicz et al., 1993; Chazal et al., 2000). By western blot analysis, we have shown that SHIP2 protein is highly expressed in proliferating neurospheres, a model of undifferentiated neural stem cells, and barely detectable in differentiated neurospheres which contain subsets of mature neurons, astrocytes and oligodendrocytes (Reynolds et al., 1992; Ben-Hur et al., 1998).

Expression of SHIP2 protein in freshly cultured astrocytes and undifferentiated neuroblastoma cells has previously been reported (Muraille et al., 1999). In this study, we have shown by in situ hybridization that, in the adult brain, SHIP2 mRNA is mainly expressed in structures containing progenitor cells of neuronal, astrocyte and oligodendrocyte lineages, whilst no expression of SHIP2 was detected in differentiated brain areas with the exception of the granular layer of cerebellum. These apparent conflicting results can be therefore explained by (i) a putative diffuse and undetectable expression of SHIP2 mRNA in differentiated neurons and/or in mature astrocytes, (ii) the induction of SHIP2 expression in cultured proliferating cells such as astrocytes and undifferentiated neuroblastoma cells as compared to its absence in quiescent cells present in vivo, as previously reported for ShcA expression (Conti et al., 1997; Cattaneo and Pelicci, 1998).

In the nervous system, growth factors such as insulinlike growth factor-I (IGF-I), nerve growth factor (NGF), brain-derived neurotrophic factor (BDNF) and basic fibroblast growth factor (bFGF) exert their effects by 
interacting with cell surface receptors that show intrinsic tyrosine kinase activity and subsequently activate PI 3-K and the Shc/Grb2/Ras/MAPK pathways. Several growth factor receptors, such as FGF receptors or IGF-I receptor, which stimulates the proliferation and inhibits the apoptosis in neurons, are restricted to the proliferative zones of the developing brain (Heuer et al., 1990; Peters et al., 1993; Bartlett et al., 1992) suggesting that they may act as mitogens and/or differentiation-inducing agents during neurogenesis and gliogenesis. This is particularly the case for bFGF which was recognized as one of the major neural stem cell mitogens (Ciccolini and Svendsen, 1998). Remarkably, the expression of the two major Shc isoforms $\left(\mathrm{ShcA}^{\mathrm{p} 46}\right.$ and $\mathrm{ShcA}^{\mathrm{p} 52}$ ) is also restricted to these proliferative VZ and SVZ (Conti et al., 1997; Cattaneo and Pelicci, 1998), both in embryonic and postnatal brain, supporting the hypothesis that the Shc isoform controls the neural stem cell proliferation. In adult brain, the adult precursor cells in the SVZa also express a set of growth factor receptors such as plateletderived growth factor (PDGF)- $\alpha$-receptor, epidermal growth factor (EGF) receptor and tyrosine kinase receptor, TrkB (Seroogy et al., 1995; Snyder et al., 1996; Oumesmar et al., 1997). Since phosphatidylinositol 5-phosphatases of the SHIP family may inhibit Ras/ MAPK activation and regulate the effect of PI 3-K activity by their ability to dephosphorylate $\operatorname{PtdIns}(3,4,5) \mathrm{P}_{3}$ (Vanhaesebroeck and Waterfield, 1999), they therefore appear to be able to regulate the growth factor signaling cascades. Neurons, astrocytes and oligodendrocytes are generated from the neural germinal zones throughout embryonic development and at adulthood (Luskin, 1998; Garcia-Verdugo et al., 1998). Therefore, the high expression of SHIP2 in these zones indicates that SHIP2 is in position to regulate the production of all neural cell types, both in embryonic and adult brain.

The enzymatic similarity between SHIP1, which acts as a negative regulator of hematopoietic cell proliferation (Liu et al., 1997, 1999; Mikhalap et al., 1999), and SHIP2 (Erneux et al., 1998), taken together with (i) the tyrosine phosphorylation of SHIP2 and its association with Shc (Habib et al., 1998) observed in response to growth factors, (ii) the overlapping distribution of IGF-I receptor, FGF receptor, Shc and SHIP2 in germinal layers, suggest a potential role for SHIP2 in the regulation of cellular division, apoptosis and differentiation of the neural stem cells in embryo and adult. Since differentiated cells rapidly lose a detectable expression of SHIP2 mRNA and protein, the control of progenitor division and survival as well as the control of the transition from proliferation to differentiation of neural cells could be the most relevant functions of this 5-phosphatase. This switch in SHIP2 expression may also constitute a new setting allowing the cell to respond differently to the same extracellular growth factor.

The tangential migration of precursors from SVZa into the olfactory bulb is associated with the expression of polysialylated N-CAM (Hu et al., 1996). The deficiency in N-CAM in knock-out mice dramatically altered this precursor migration with no change in the proliferation or rate of death of these cells. This results in an accumulation of neural precursors along the rostral migratory stream and a reduction in the olfactory bulb size due to a decreased density in granule cells and periglomerular neurons (Cremer et al., 1994; Chazal et al., 2000). The very high level of SHIP2 expression in the enlarged rostral migratory stream and SVZa definitively demonstrated that in adulthood, this 5-phosphatase is selectively expressed in neural precursors and not in the overlying white matter (corpus callosum) as recently claimed by Kudo et al. (2000) based on in situ hybridization in the rat. Moreover, the high SHIP2 expression in these precursor cells also suggests that they retain some of their phenotypical characteristics despite of their dramatic migration defect.

In the periphery, we have observed a large distribution of SHIP2 mRNA. SHIP2 is highly expressed in muscular tissues and in the cortex of kidney. A moderate signal is detected in thyroid, pituitary gland, digestive system and bone. This large distribution, in addition with the fact that SHIP2 is tyrosine phosphorylated in response to numerous growth factors stimulating tyrosine kinase receptors (Habib et al., 1998), suggest the implication of SHIP2 in different systems. Although the functional roles of SHIP2 in these organs remain unclear, our study suggests several interesting ways of research. For example, the intense SHIP2 signal observed in muscular tissues at all embryonic stages could be correlated to the implication of SHIP2 as a negative regulator in the insulin-dependent PI 3-K activation pathways (Isihara et al., 1999; Clément et al., 2001).

\section{CONCLUSION}

The pattern of SHIP2 expression in the brain germinal epithelium, where it is susceptible to tyrosine phosphorylation by stimulation with exogenous factors, correlates with the proliferative and early differentiative events that occur in the brain. This suggests that this 5-phosphatase may have important roles in neural development and may define a completely new pathway to control the switch between proliferation and differentiation of immature neuroblasts. SHIP2 expression in neural stem cells at early and late embryonic stages as well as at adulthood indicates that these roles may concern both neuroblasts and proliferating glial elements including reactive astrocytes in adult injured brain. The precise functional roles of SHIP2 in the control of neural stem cell proliferation, apoptosis and/or differentiation remain to be elucidated. Nevertheless, this phosphatase appears as a promising pharmacological target for the manipulation of embryonic or adult-derived stem cells of VZ or SVZa in vitro, in order to develop new repair strategies for cell transplantation into the injured brain.

Acknowledgements - We thank Mrs. Michèle Authelet for technical assistance in the initial part of this work. We would like to thank Xavier Pesesse for providing the $\mathrm{SH} 2$ antibodies and Colette Moreau for the help in western blot analysis. This 
work was supported by grants of the Fonds de la Recherche Scientifique Médicale (3.4551.98) (Belgium), Action de Recherche Concertée of the Communauté Française de Belgique (Belgium), Fondation Médicale Reine Elisabeth (Neurobiologie 1999-2001) (Belgium), by the Belgian Program on Interuniver- sity Poles of Attraction initiated by the Belgian state. E.M. is supported by a grant from E.U. biomed 2 program BMH4-CT972609 and a grant 'Chargé de Recherche' from the Fond National de la Recherche Scientifique (Belgium); D.D. is supported by the Hoguet Fondation (Belgium).

\section{REFERENCES}

Altman, J., Bayer, S.A., 1995. Atlas of Prenatal Rat Brain Development. CRC Press, Boca Raton, FL.

Bartlett, W.P., Li, X.S., Williams, M., 1992. Expression of IGF-1 mRNA in the murine subventricular zone during postnatal development. Mol. Brain Res. 12, 285-291.

Ben-Hur, T., Rogister, B., Murray, K., Rougon, G., Dubois-Dalcq, M., 1998. Growth and fate of PSA-NCAM+ precursors of the postnatal brain. J. Neurosci. 18, 5777-5788.

Cattaneo, E., Pelicci, P.G., 1998. Emerging roles for SH2/PTB-containing Shc adaptor proteins in the developing mammalian brain. Trends Neurosci. 21, 476-481.

Chazal, G., Durbec, P., Jankovski, A., Rougon, G., Cremer, H., 2000. Consequences of neural cell adhesion molecule deficiency on cell migration in the rostral migratory stream of the mouse. J. Neurosci. 20, 1446-1457.

Ciccolini, F.N., Svendsen, C.N., 1998. Fibroblast growth factor 2 (FGF-2) promotes acquisition of epidermal growth factor (EGF) responsiveness in mouse striatal precursor cells: Identification of neural precursors responding to both EGF and FGF-2. J. Neurosci. 18, 7869-7880.

Clément, S., Krause, U., Desmedt, F., Tanti, J.-F., Behrends, J., Pesesse, X., Sasaki, T., Penninger, J., Doherty, M., Malaisse, W., Dumont, J.E., Le Marchand-Brustel, Y., Erneux, C., Hue, L., Schurmans, S., 2001. The lipid phosphatase SHIP2 controls insulin sensitivity. Nature 409, 9297.

Coggeshall, K.M., 1998. Inhibitory signaling by B cell Fc gamma RIIb. Curr. Opin. Immunol. 10, 306-312.

Conti, L., De Fraja, C., Gulisano, M., Migliaccio, E., Govoni, S., Cattaneo, E., 1997. Expression and activation of SH2/PTB-containing ShcA adaptor protein reflects the pattern of neurogenesis in the mammalian brain. Proc. Natl. Acad. Sci. USA 94, 8185-8190.

Cremer, H., Lange, R., Christoph, A., Plomann, M., Vopper, G., Roes, J., Brown, R., Baldwin, S., Kraemer, P., Scheff, S. et al., 1994. Inactivation of the N-CAM gene in mice results in size reduction of the olfactory bulb and deficits in spatial learning. Nature 367, 455-459.

Doetsch, F., Alvarez-Buylla, A., 1996. Network of tangential pathways for neuronal migration in adult mammalian brain. Proc. Natl. Acad. Sci. USA 93, 14895-14900.

Dolcet, X., Egea, J., Soler, R.M., Martin-Zanca, D., Comella, J.X., 1999. Activation of phosphatidylinositol 3-kinase, but not extracellularregulated kinases, is necessary to mediate brain-derived neurotrophic factor-induced motoneuron survival. J. Neurochem. 73, 521-531.

Drayer, A.L., Pesesse, X., De Smedt, F., Woscholski, R., Parker, P., Erneux, C., 1996. Cloning and expression of a human placenta inositol 1,3,4,5-tetrakisphosphate and phosphatidylinositol 3,4,5-trisphosphate 5-phosphatase. Biochem. Biophys. Res. Commun. 225, 243-249.

Erneux, C., Govaerts, C., Communi, D., Pesesse, X., 1998. The diversity and possible functions of the inositol polyphosphate 5-phosphatases. Biochim. Biophys. Acta 1436, 185-199.

Feldman, E.L., Sullivan, K.A., Kim, B., Russell, J.W., 1997. Insulin-like growth factors regulate neuronal differentiation and survival. Neurobiol Dis. 4, 201-214.

Garcia-Verdugo, J.M., Doetsch, F., Wichterle, H., Lim, D.A., Alvarez-Buylla, A., 1998. Architecture and cell types of the adult subventricular zone: in search of the stem cells. J. Neurobiol. 36, 234-248.

Goldman, S.A., Kirschenbaum, B., Harrison-Restelli, C., Thaler, H.T., 1997. Neuronal precursors of the adult rat subependymal zone persist into senescence, with no decline in spatial extent or response to BDNF. J. Neurobiol. 32, 554-566.

Habib, T., Hejna, J.A., Moses, R.E., Decker, S.J., 1998. Growth factors and insulin stimulate tyrosine phosphorylation of the 51C/SHIP2 protein. J. Biol. Chem. 273, 18605-18609.

Helgason, C.D., Damen, J.E., Rosten, P., Grewal, R., Sorensen, P., Chappel, S.M., Borowski, A., Jirik, F., Krystal, G., Humphries, R.K., 1998. Targeted disruption of SHIP leads to hemopoietic perturbations, lung pathology, and a shortened life span. Genes Dev. 12, 1610-1620.

Heuer, J.G., von Bartheld, C.S., Kinoshita, Y., Evers, P.C., Bothwell, M., 1990. Alternating phases of FGF receptor and NGF receptor expression in the developing chicken nervous system. Neuron 5, 283-296.

Hu, H., Tomasiewicz, H., Magnuson, T., Rutishauser, U., 1996. The role of polysialic acid in migration of olfactory bulb interneuron precursors in the subventricular zone. Neuron 16, 735-743.

Hunter, M.G., Avalos, B.R., 1998. Phosphatidylinositol 3'-kinase and SH2-containing inositol phosphatase (SHIP) are recruited by distinct positive and negative growth-regulatory domains in the granulocyte colony-stimulating factor receptor. J. Immunol. 160, 4979-4987.

Ishihara, H., Sasaoka, T., Hori, H., Wada, T., Hirai, H., Haruta, T., Langlois, W.J., Kobayashi, M., 1999. Molecular cloning of rat SH2 containing inositol phosphatase 2 (SHIP2) and its role in the regulation of insulin signaling. Biochem. Biophys. Res. Commun. 260, 265-272.

Kavanaugh, W.M., Pot, D.A., Chin, S.M., Deuter-Reinhard, M., Jefferson, A.B., Norris, F.A., Masiarz, F.R., Cousens, L.S., Majerus, P.W., Williams, L.T., 1996. Multiple forms of an inositol polyphosphate 5-phosphatase form signaling complexes with Shc and Grb2. Curr. Biol. 6, 438-445.

Klesse, L.J., Parada, L.F., 1998. p21 ras and phosphatidylinositol-3 kinase are required for survival of wild-type and NF1 mutant sensory neurons J. Neurosci. 18, 10420-10428

Kudo, M., Saito, S., Owada, Y., Suzaki, H., Kondo, H., 2000. Localization of mRNA for SHIP2, SH2 domain-containing inositol polyphosphate 5-phosphatase, in the brain of developing and mature rats. Mol. Brain Res. 75, 172-177.

Liu, L., Damen, J.E., Hughes, M.R., Babic, I., Jirik, F.R., Krystal, G., 1997. The Src homology 2 (SH2) domain of SH2-containing inosito phosphatase (SHIP) is essential for tyrosine phosphorylation of SHIP, its association with Shc, and its induction of apoptosis. J. Biol. Chem. 272, 8983-8988.

Liu, Q., Sasaki, T., Kozieradzki, I., Wakeham, A., Itie, A., Dumont, D.J., Penninger, J.M., 1999. SHIP is a negative regulator of growth factor receptor-mediated PKB/Akt activation and myeloid cell survival. Genes Dev. 13, 786-791.

Liu, Q., Shalaby, F., Jones, J., Bouchard, D., Dumont, D.J., 1998. The SH2-containing inositol polyphosphate 5-phosphatase, ship, is expressed during hematopoiesis and spermatogenesis. Blood 91, 2753-2759.

Luskin, M.B., 1993. Restricted proliferation and migration of postnatally generated neurons derived from the forebrain subventricular zone. Neuron 11, 173-189.

Luskin, M.B., 1998. Neuroblasts of the postnatal mammalian forebrain: their phenotype and fate. J. Neurobiol. 36, 221-233.

Majerus, P.W., Kisseleva, M.V., Norris, F.A., 1999. The role of phosphatases in inositol signaling reactions. J. Biol. Chem. 274 , $10669-10672$.

McKay, R., 1997. Stem cells in the central nervous system. Science 276, 66-71. 
Mikhalap, S.V., Shlapatska, L.M., Berdova, A.G., Law, C.L., Clark, E.A., Sidorenko, S.P., 1999. CDw150 associates with src-homology 2containing inositol phosphatase and modulates CD95-mediated apoptosis. J. Immunol. 162, 5719-5727.

Ming, G., Song, H., Berninger, B., Inagaki, N., Tessier-Lavigne, M., Poo, M., 1999. Phospholipase C-gamma and phosphoinositide 3-kinase mediate cytoplasmic signaling in nerve growth cone guidance. Neuron 23, 139-148.

Muraille, E., Bruhns, P., Pesesse, X., Daëron, M., Erneux, C., 2000. The SH2 domain containing inositol 5-phosphatase SHIP2 associates to the immunoreceptor tyrosine-based inhibition motif of Fc $\gamma$ RIIB in B cells under negative signaling. Immunol. Lett. 72, 7-15.

Muraille, E., Pesesse, X., Kuntz, C., Erneux, C., 1999. Distribution of the src-homology-2-domain-containing inositol 5-phosphatase SHIP-2 in both non-haemopoietic and haemopoietic cells and possible involvement of SHIP-2 in negative signalling of B-cells. Biochem. J. 3, 697-705.

Oumesmar, B.N., Vignais, L., Baron-Van Evercooren, A., 1997. Developmental expression of platelet-derived growth factor alpha-receptor in neurons and glial cells of the mouse CNS. J. Neurosci. 17, 125-139.

Pesesse, X., Deleu, S., De Smedt, F., Drayer, L., Erneux, C., 1997. Identification of a second SH2-domain-containing protein closely related to the phosphatidylinositol polyphosphate 5-phosphatase SHIP. Biochem. Biophys. Res. Commun. 239, 697-700.

Pesesse, X., Moreau, C., Drayer, A.L., Woscholski, R., Parker, P., Erneux, C., 1998. The SH2 domain containing inositol 5-phosphatase SHIP2 displays phosphatidylinositol 3,4,5-trisphosphate and inositol 1,3,4,5-tetrakisphosphate 5-phosphatase activity. FEBS Lett. 437, 301-303.

Peters, K., Ornitz, D., Werner, S., Williams, L., 1993. Unique expression pattern of the FGF receptor 3 gene during mouse organogenesis. Dev. Biol. 155, 423-430

Pradhan, M., Coggeshall, K.M., 1997. Activation-induced bi-dentate interaction of SHIP and Shc in B lymphocytes. J. Cell Biochem. 67, 32-42.

Reynolds, B.A., Tetzlaff, W., Weiss, S., 1992. A multipotent EGF-responsive striatal embryonic progenitor cell produces neurons and astrocytes. J. Neurosci. 12, 4565-4574.

Rohrschneider, L.R., Fuller, J.F., Wolf, I., Liu, Y., Lucas, D.M., 2000. Structure, function, and biology of SHIP proteins. Genes Dev. 14, 505520.

Schamra, U.B., Lauder, J.M., Silver, J., 1992. Atlas of Prenatal Mouse Brain. Academic Press, New York.

Scharenberg, A.M., El-Hillal, O., Fruman, D.A., Beitz, L.O., Li, Z., Lin, S., Gout, I., Cantley, L.C., Rawlings, D.J., Kinet, J.P., 1998. Phosphatidylinositol-3,4,5-trisphosphate (PtdIns-3,4,5-P3)/Tec kinase-dependent calcium signaling pathway: a target for SHIP-mediated inhibitory signals. EMBO J. 17, 1961-1972.

Schiffmann, S.N., Bernier, B., Goffinet, A.M., 1997. Reelin mRNA expression during mouse brain development. Eur. J. Neurosci. 9, 1055-1071.

Schiffmann, S.N., Vanderhaegen, J.J., 1991. Distribution of cells containing mRNA encoding cholecystokinin in the rat central nervous system. J. Comp. Neurol. 304, 219-233.

Schurmans, S., Carrio, R., Behrends, J., Pouillon, V., Merino, J., Clement, S., 1999. The mouse SHIP2 (Inppl1) gene: complementary DNA, genomic structure, promoter analysis, and gene expression in the embryo and adult mouse. Genomics 62, 260-271.

Seroogy, K.B., Gall, C.M., Lee, D.C., Kornblum, H.I., 1995. Proliferative zones of postnatal rat brain express epidermal growth factor receptor mRNA. Brain Res. 670, 157-164.

Shimoke, K., Kubo, T., Numakawa, T., Abiru, Y., Enokido, Y., Takei, N., Ikeuchi, T., Hatanaka, H., 1997. Involvement of phosphatidylinositol3 kinase in prevention of low $\mathrm{K}(+)$-induced apoptosis of cerebellar granule neurons. Brain Res. Dev. Brain Res. 101, 197-206.

Snyder, S.E., Li, J., Schauwecker, P.E., McNeill, T.H., Salton, S.R., 1996. Comparison of RPTP zeta/beta, phosphacan, and trkB mRNA expression in the developing and adult rat nervous system and induction of RPTP zeta/beta and phosphacan mRNA following brain injury. Mol. Brain Res. 40, 79-96.

Theiler, K., 1989. The House Mouse. Atlas of Embryonic Development. Springer, New York.

Tomasiewicz, H., Ono, K., Yee, D., Thompson, C., Goridis, C., Rutishauser, U., Magnuson, T., 1993. Genetic deletion of a neural cell adhesion molecule variant (N-CAM-180) produces distinct defects in the central nervous system. Neuron 11, 1163-1174.

Tridandapani, S., Phee, H., Shivakumar, L., Kelley, T.W., Coggeshall, K.M., 1998. Role of SHIP in FcgammaRIIb-mediated inhibition of Ras activation in B cells. Mol. Immunol. 35, 1135-1146.

Tropepe, V., Sibilia, M., Ciruna, B.G., Rossant, J., Wagner, E.F., van der Kooy, D., 1998. Distinct neural stem cells proliferate in response to EGF and FGF in the developing mouse telencephalon. Dev. Biol. 208, 166-188.

Vaillant, A.R., Mazzoni, I., Tudan, C., Boudreau, M., Kaplan, D.R., Miller, F.D., 1999. Depolarization and neurotrophins converge on the phosphatidylinositol 3-kinase-Akt pathway to synergistically regulate neuronal survival. J. Cell Biol. 146, 955-966.

Vanderwinden, J.M., Mailleux, P., Schiffmann, S.N., Vanderhaegen, J.J., 1992. Cellular distribution of the new growth factor pleiotrophin (HBGAM) mRNA in developing and adult rat tissues. Anat. Embryol. Berl. 186, 337-406.

Vanhaesebroeck, B., Waterfield, M.D., 1999. Signaling by distinct classes of phosphoinositide 3-kinases. Exp. Cell Res. 253, 239-254

Wolf, I., Lucas, D.M., Algate, P.A., Rohrschneider, L.R., 2000. Cloning of the genomic locus of mouse SH2 containing inositol 5-phosphatase (SHIP) and a novel 110-kDa splice isoform, SHIP. Genomics 69, 104-112.

(Accepted 11 May 2001) 